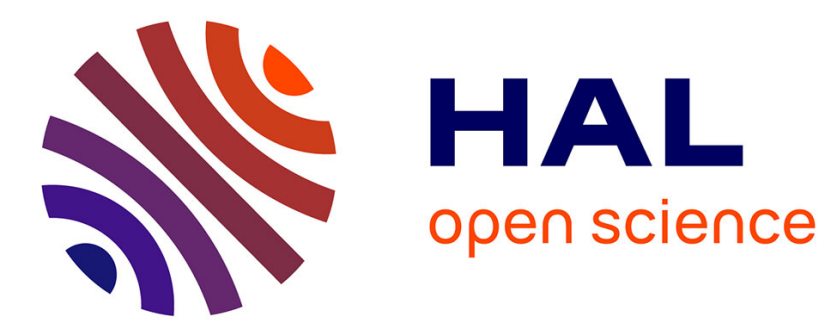

\title{
Sodium arsenite effect on Vitis vinifera L. Physiology
} Aurélie Songy, Julie Vallet, Marie Gantet, Anne Boos, Pascale Ronot, Céline Tarnus, Christophe Clément, Philippe Larignon, Mary-Lorène Goddard, Florence Fontaine

\section{- To cite this version:}

Aurélie Songy, Julie Vallet, Marie Gantet, Anne Boos, Pascale Ronot, et al.. Sodium arsenite effect on Vitis vinifera L. Physiology. Journal of Plant Physiology, 2019, 238, pp.72-79. 10.1016/j.jplph.2019.05.010 . hal-02271676

\section{HAL Id: hal-02271676 https://hal.science/hal-02271676}

Submitted on 25 Oct 2021

HAL is a multi-disciplinary open access archive for the deposit and dissemination of scientific research documents, whether they are published or not. The documents may come from teaching and research institutions in France or abroad, or from public or private research centers.
L'archive ouverte pluridisciplinaire HAL, est destinée au dépôt et à la diffusion de documents scientifiques de niveau recherche, publiés ou non, émanant des établissements d'enseignement et de recherche français ou étrangers, des laboratoires publics ou privés.

\section{(c) (1) $\$$}

Distributed under a Creative Commons Attribution - NonCommercial| 4.0 International 
1 Sodium arsenite effect on Vitis vinifera L. physiology.

2

3 Aurélie Songy ${ }^{\mathrm{a} \dagger}$, Julie Vallet ${ }^{\mathrm{a} \dagger}$, Marie Gantet ${ }^{\mathrm{a}}$, Anne Boos ${ }^{\mathrm{b}, \mathrm{c}}$, Pascale Ronot ${ }^{\mathrm{b}, \mathrm{c}}$, Céline

4 Tarnus $^{\mathrm{d} \$}$, Christophe Clément ${ }^{\mathrm{a}}$, Philippe Larignon ${ }^{\mathrm{f}}$, Mary-Lorène Goddard ${ }^{\mathrm{d}, \mathrm{e}}$, Fontaine

5 Florence $^{\mathrm{a}^{*}}$

6

$7 \quad{ }^{a}$ SFR Condorcet CNRS 3417, URCA, Résistance Induite et Bioprotection des Plantes EA

8 4707, BP 1039, 51687 Reims Cedex 2, France. ${ }^{\text {b} U n i v e r s i t e ́ ~ d e ~ S t r a s b o u r g, ~ I P H C, ~} 25$ rue

9 Becquerel, 67087 Strasbourg, France, ${ }^{c}$ CNRS, UMR7178, 67087 Strasbourg, France.

10 d'Laboratoire d'Innovation Moléculaire et Applications, Université de Haute-Alsace,

11 Université de Strasbourg, CNRS, LIMA, UMR 7042, 3bis rue Alfred Werner, 68093

12 Mulhouse cedex, France. ${ }^{\mathrm{e}}$ Laboratoire Vigne, Biotechnologies et Environnement, LVBE,

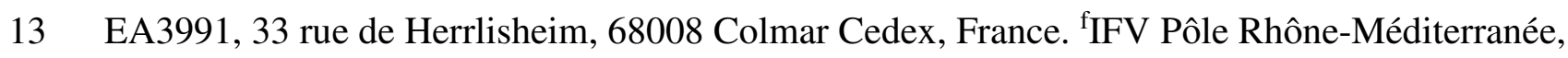

147 avenue Cazeaux, 30230 Rodilhan, France.

15

$16 \dagger$ These authors contributed equally to this work

17 \$ Present address: Laboratoire Vigne, Biotechnologies et Environnement, LVBE, EA3991, 33

18 rue de Herrlisheim, 68008 Colmar Cedex, France

19

$20 *$ Corresponding author: florence.fontaine@univ-reims.fr 
Sodium arsenite $\left(\mathrm{NaAsO}_{2}\right)$ was especially used as a dormant spray to control grapevine trunk diseases (GTDs) in European vineyards until 2003 when it was banned. It was an efficient product but it was banned due to high risk for human health and the environment. Now, as one of the consequences with climatic changes, GTDs threaten the sustainability of vineyards since no similar and efficacious sprays are presently available to reduce the impact of GTDs. Research efforts were devoted to identify other active ingredients and biological control agents but they remained limited in term of efficacy. New solutions might follow from a better understanding of the modes of action of sodium arsenite which are currently lacking, specially its impact on grapevine physiology. For this study, grafted plants cv. Tempranillo were sprayed by sodium arsenite at the end of the winter. During the vegetative period, the impact on plant physiology was studied by measurement of the photosynthetic activity, the vine growth and development, and some defense responses. Our results showed that arsenic was translocated throughout the vine with an increasing gradient from the leaves to the root system, that photosynthesis was firstly reduced and then stimulated, and that plant tolerance responses were induced especially antioxidant system. The activation of grapevine defense responses by sodium arsenite could be a complementary action to fight fungal pathogens in addition to the fungicide effect.

Keywords: sodium arsenite, Tempranillo, photosynthesis, plant physiology, plant response, translocation 


\section{Introduction}

In agriculture, arsenic-based compounds were used firstly as insecticides in the 18th century. Such treatments were applied to control Leptinotarsa decemlineata in potatoes (Riley, 1876), Aclypea opaca in sugar beet (Grosjean, 1896) and Anthonomus grandis in cotton (Robinson, 1926) and Anthonomus quadrigibus in apple tree (Quaintance and Scott, 1912) as examples.

In the 19th century, arsenic compounds were then used as herbicides in either their inorganic forms, like sodium arsenite, or their organic forms (Schultz and Thompson, 1925; Hood, 1985). In viticulture, they were also employed as insecticides against Sparganothis pilleriana (Marchal, 1919), Eupoecilia ambiguella (Capus and Feytaud, 1909) and Lobesia botrana (Capus and Feytaud, 1909). More recently, their use as fungicides was tested at the beginning of the 20th century, especially to manage grapevine trunk diseases (GTDs) (Ravaz, 1919, 1924; Viala, 1926, Desaché et al., 1995), anthracnose (Vergnes, 1957) and Phomopsis cane and leaf spot (Hewitt, 1951). Other sporadic applications to limit the attacks by snails was reported by Vidal (1947).

Due to the high risks of sodium arsenite for humans and the environment (Spinosi et al., 2009), its use in agriculture was banned in Europe, especially in 2003 for viticulture. In viticulture, this withdrawal was not without consequences since no other active chemical spray treatment was available to reduce the impact of GTDs. These diseases are due to a complex of fungal pathogens which are inhabit wood (Mondello et al., 2018a). For GTDs, fungi infect the vine especially by pruning wounds which then colonize the trunk and other woody organs (Mugnai et al., 1999; Bertsch et al., 2013). The pathogens may live inside the vine as asymptomatic endophytes and after some period of latency that is typically interrupted by stress to the vine, the vine might express foliar symptoms and be thus considered as a symptomatic vine. GTD foliar symptoms can be characterized by neither a sudden wilting of the whole plant or part of the plant, namely apoplectic symptoms or apoplexy, or discoloration with a typical tiger-stripe pattern or chlorosis in the case of the chronic form (Mugnai et al., 1999; Mondello et al., 2018a).

A recent International Organisation of Vine and Wine (OIV) publication reported that in European countries such as France, Spain and Italy, the incidence of GTDs varied from 8 to 19\% (Fontaine et al., 2016) and 13\% of unproductive vineyard represented a loss estimated of $€ 1$ billion in 2014. In USA, especially California, and in Australia, losses were US \$ 260 million and AUS \$8.3 billion per year. Until 2003 and especially in Europe, the sodium arsenite was the sole product available to inhibit foliar symptoms of GTDs, especially Esca diseases. The effect was less against Eutypa lata, causal agent of eutypa dieback, and on 
81 Botryosphaeriaceae spp. close to this reported on esca pathogens (Larignon et al., 2008).

82 Since its ban, their incidence has increased because no product as efficient as sodium arsenite was available for application. Researches were conducted to control Esca disease and they were based especially on pruning wound protection (for review Mondello et al., 2018a), the main way for the causal agents to infect the grapevine, by trunk renewal (Mondello et al., 2018 b), and by chemicals or biocontrol agents, prophylactic methods or the use of biostimulant/elicitors (for review Mondello et al., 2018a,b).

The limits to develop a new product with similar effects induced by sodium arsenite to control Esca disease are the gaps of knowledge on its mode of action. To date, no definitive mechanism has clearly been identified to explain how sodium arsenite acts in suppressing foliar symptoms. An explanation could be the effect of arsenic on plant physiology whose resulting perturbations could induce the appearance of symptoms (Magnin-Robert et al., 2011, Magnin-Robert et al., 2017, for review Fontaine et al., 2015). On this basis, it seems relevant to take an interest in the effects of sodium arsenite on the grapevine physiology. Nevertheless, no scientific publication deals specifically with the incidence of arsenic compounds on grapevine physiology. After the vineyard treatment with sodium arsenite, CarbonellBarrachina et al. (1997a) observed a decrease of sodium arsenite concentration throughout the vegetative cycle and no accumulation of arsenic in leaves and fruits after three-years of treatment, due to a possible exudation into the soil from roots. Similarly, Larignon et al. (2008) conducted sodium arsenite treatment in vineyard and measured a greater concentration of arsenic in the trunk than in the leaves and the fruits, especially in the wood necrosis areas. They also reported no change in the contents of proanthocyanidic tannins and total soluble phenolic compounds in the healthy wood and in the periphery of the white rot. Finally, Santos et al. (2006) noticed that in vitro grapevine plants, treated by sodium arsenite, developed leaf senescence symptoms like a decrease of chlorophyll content, of leaf fluorescence and of growth in fresh weight, as well as an increase of lipid peroxidation.

108 For other crops, few papers reported that this compound can penetrate into woody tissues and 109 move inside the plant from roots to shoots and berries, and can be excreted in the soil (for review Li et al., 2016, Latowski et al., 2018). Regarding its impact on plant physiology, numerous disorders are triggered by arsenic, leading to plant growth and productivity decline,

112 the alteration of ATP synthesis and photosynthesis, and the impact on membrane integrity and 113 nutrient acquisition (for reviews, see Abbas et al., 2018, Chandrakar, 2018, Kofroñova et al., 114 2018). Due to the interactions of As(III) with sulfhydryl groups (-SH) of enzymes and the 
115 ROS generation, plant metabolism is severely altered, notably the carbohydrate, lipid and 116 protein metabolisms, and the DNA structure (for review Finnegan and Chen, 2012, Abbas et 117 al., 2018). Detoxification mechanisms were also induced in plants but not studied intensively 118 (Srivastava et al., 2007; Kumar et al., 2015).

119 There was interest to develop a mimic product to sodium arsenite to optimize the control of

120 GTDs, especially Esca disease but also both Eutypa and Botryosphaeria diebacks, and other 121 diseases managed in the past by the use of sodium arsenite. This involved the understanding 122 of the relationship between the application, its penetration and translocation within the plant, 123 and the impact on growth and physiology all may help to find a mimic product. The main 124 goal of this study is thus to intensively study the impact of sodium arsenite on grapevine 125 growth distinguishing both aerial and root systems, and on physiology focusing on the 126 carbohydrate metabolism and plant defense response. For this reason, photosynthetic activity 127 was measured and the expressions of targeted genes especially involved in defense response 128 and stress tolerance were monitored.

\section{Material and Methods}

\subsection{Plant material, treatment with sodium arsenite and sampling} In 2013, 1-year-old Vitis vinifera cv. Aragonez (="Tempranillo"), defined as susceptible

133 cultivar to GTDs, grafted on rootstock 1103P grapevine were potted individually in a 1 liter

134 pot containing a sandy soil mixture (one-third sand, one-third soil, and one-third organic matter) and they grew under natural conditions (Figures 1S, 2S). In 2015 (March $5^{\text {th }}$ ) and in 2016 (March 10 ${ }^{\text {th }}$ ), dormant vines were sprayed with $1250 \mathrm{~g} / \mathrm{hl}$ of sodium arsenite (PyralEsca), i.e. the vineyard concentration normally applied. The solution was sprayed using a manual sprayer until runoff. The experimentation was conducted twice and according to a completely randomized design: in 2015, 10 control plants and 10 plants treated with sodium arsenite according to the vineyard concentration $(1250 \mathrm{~g} / \mathrm{hl})$; and in 2016, 20 control plants, 20 treated plants at $1250 \mathrm{~g} / \mathrm{hl}$ and 20 treated plants at $312.5 \mathrm{~g} / \mathrm{hl}$ of sodium arsenite, i.e. one quarter of

142 the prior application rate.

143 Samples were collected at flowering (half of the plants) and at berry maturity (half of the 144 plants), respectively approximately 3 months ( $T+90$ days in 2015 and $T+87$ in 2016) and 6 145 months ( $\mathrm{T}+183$ days in 2015 and $\mathrm{T}+178$ days in 2016) after the treatment date ( $\mathrm{T})$. The collected plants were used to measure morphological parameters and quantify total arsenic concentration. Then, samples of leaves in the intermediate zone, green stems and root for each treatment were frozen in liquid nitrogen and then stored at $-80^{\circ} \mathrm{C}$ until molecular analysis. 
149 Flowering and berry maturity were selected since they are 2 significant phenological stages in

150 the grapevine reproductive development and because of important sap flows that could promote the translocation of arsenic within the whole plant.

\subsection{Quantification of total arsenic}

154 Total arsenic was quantified at flowering and at berry maturity, i.e. 3 and 6 months after the 155 treatment respectively, in the grafted plant and soil. For the plant, the analysis was performed 156 on leaves, on the trunk below the graft/bud union and on roots. Ten ( 5 controls and 5 treated) 157 and 15 (5 controls, 5 As treated, 5 As 1/4 treated) samples per treatment were analyzed in 2015 and 2016 respectively. Each plant sample was cut in small pieces of $1 \mathrm{~cm}^{3}$. Plant and soil samples were then lyophilized.

160 All grapevine organs (roots, trunk and leaves) and soil (0.25 g) samples were digested with

$1613.0 \mathrm{~mL}$ of $69 \%$ nitric acid (trace analytical grade, Acros organic) and $1.0 \mathrm{~mL}$ of ultrapure 162 water for $35 \mathrm{~min}$ at $200^{\circ} \mathrm{C}$ after $10 \mathrm{~min}$ of temperature increase in a microwave digester 163 (Anton Paar, ECO). After mineralization, the volume is made up to $20 \mathrm{~mL}$ with ultrapure water. Blanks were prepared in the same way, omitting the sample. The obtained digested solutions are 20 times diluted and the concentrations of total arsenic in the grapevine and soil samples were determined using inductively coupled plasma-mass spectrometry (ICP-MS). ICP-MS (Agilent 7500ce) is equipped with a Peltier cooled Scott spray chamber, a pneumatic nebulizer (1 $\mathrm{mL} \mathrm{min}^{-1}$, Glass Expansion), and an inert PFA sample introduction system. The 7500ce instrument uses a collision reaction cell with Helium gas technology to remove polyatomic interferences (mainly $\mathrm{ArCl}^{+}$). The optimized operating conditions are summarized in Table $1 \mathrm{~S}$. The monitored isotope was ${ }^{75} \mathrm{As}$ and ${ }^{121} \mathrm{Sb}$ at $10 \mathrm{ppb}$ was used as internal standard (prepared from $1000 \mathrm{mg} \mathrm{L}^{-1}$ As and Sb certified standard solutions (CPI International) diluted in $1 \% \mathrm{v} / \mathrm{v} \mathrm{HNO}_{3}$ solution). All the grapevine samples were analyzed in triplicates.

\subsection{Measurement of plant growth}

176 On each plant, the fresh weight and the volume of the root, and the number, the length and the

177 diameter of the shoots were measured according to the laboratory protocol in order to evaluate 178 the effect of the treatment on the plant development. The root system volume was estimated 179 by water displacement. To avoid bias linked to the smaller shoots lastly grown, the mean 180 diameters and lengths of the shoots corresponds to the means of the first three thicker and 181 longer shoots. The shoots diameter corresponds to the diameter at the base of the first 182 internode. The measurements were realized at both kinetic points, flowering and berry 
183

maturity, and each year. Five biological replicates per condition and per kinetic point were used in 2015 and ten in 2016.

\subsection{Measurement of photosynthetic activity}

Net photosynthesis $\left(\mathrm{A}_{\mathrm{n}}\right)$, stomatal conductance $\left(\mathrm{g}_{\mathrm{s}}\right)$, internal leaf $\mathrm{CO}_{2}$ concentration $(\mathrm{C} \mathrm{i})$ and transpiration (E) were determined simultaneously on leaves with a portable infrared gas analysis system (Li-Cor Model 6400-XT, Lincoln, NE) using a standard leaf. Water use efficiency (WUE) was determined by the ratio of $\left(A_{n} / g_{s}\right)$ which provides the loss of water relative to the $\mathrm{CO}_{2}$ assimilation (Epron and Dreyer, 1993). Measurements were conducted between 8:00 a.m. and 12:00 a.m. before the "midday depression" (i.e., the minimal $\mathrm{A}_{\mathrm{n}}$ linked mainly to stomata closure) (Chaumont et al., 1994). The infrared gas analysis system was equipped with a clamp-on leaf cuvette that exposed $6 \mathrm{~cm}^{2}$ of leaf area. Environmental conditions during photosynthetic measurements were the following: photosynthetic active radiation $=1,000 \mu \mathrm{mol} \mathrm{m} \mathrm{m}^{-2} \mathrm{~s}^{-1}$, relative humidity $\approx 50 \%$, and chamber temperature of $24^{\circ} \mathrm{C}$. $\mathrm{CO}_{2}$ was maintained at a constant level $\left(380 \mu \mathrm{mol} . \mathrm{L}^{-1}\right)$ using a LI-6400-01 $\mathrm{CO}_{2}$ injector with a high-pressure liquid $\mathrm{CO}_{2}$ cartridge source. At the same time and only in 2015, the photosystem II activity (ФPSII) was evaluated using a FMS2 chlorophyll fluorometer (Hansatech Instruments, United Kingdom). The photosynthesis measurements of each plant correspond to the mean of 3 measures made on 3 leaves located at the bottom, middle and top of the canopy. They were conducted on 5 biological replicates per condition in 2015 and on 10 biological replicates per condition in 2016. Measurements were performed on the same leaves from flowering (i.e. 3 months after treatment) until the berry maturity (i.e. 6 months after treatment) and every 2 weeks.

\subsection{Molecular analysis by $q R T-P C R$}

The analysis was performed on leaves, green stems and roots of control and treated plants collected at timepoints flowering and berry maturity, as for other analyses. For each plant, after grinding of the different samples, total RNA of leaves, green stems and roots were extracted from $50 \mathrm{mg}, 100 \mathrm{mg}$ and $150 \mathrm{mg}$ of powder respectively. Total RNA was isolated using a $\beta$-mercaptoethanol and sodium acid-based protocol according to Spagnolo et al. (2012) for green stem and Magnin-Robert et al. (2014) for leaves and roots. In total $150 \mathrm{ng}$ of total RNA was reverse-transcribed using Verso SYBR 2-step QRT ROX enzyme (ABgene, Surrey, UK) according to the manufacturer's protocol. PCR conditions were those described by Bézier et al. (2002). The expression of selected genes according to the organ, summarized in 
217 Table 1, was tracked by quantitative RT-PCR. The data were analyzed using CFX Manager

218 software, and the relative levels of gene expression were determined following the method of

219 Hellemans et al. (2007) with either EF1 $\alpha$ (leaf, green stem and root), 60SRP (leaf) or UBE2

220 (green stem and root) used as internal reference genes according to the organ (Table 1).

221 Results correspond to the relative gene expression in organs of treated plants at flowering and

222 at berry maturity compared to the controls at corresponding timepoints. The value obtained

223 for one treated plant correspond to the mean of the values of the relative gene expression of

224 the treated plant compared to each individual control. In 2015, five biological replicates were

225 used per condition and ten in 2016. The analyzed genes were considered up- or down-

226 regulated when the value of relative expression was $>2$-fold or $<0.5$-fold compared to the

227 controls, respectively.

\subsection{Statistical analysis}

231 Statistical tests were performed on R 3.3.3 software. For the arsenic content analysis, a

232 Shapiro-Wilk test was done to check the normality of data. As the normality was not assumed

233 in all cases, a nonparametric test of bivariate Wilcoxon was performed when the mean of

234 arsenic and control were compared. The meaning of different symbols is ns ( $>0.05)$, *

$235(\mathrm{p}<0.05), * *(\mathrm{p}<0.01)$ and $* * *(\mathrm{p}<0.001)$. While the mean of three modalities were compared

236 (As, As $1 / 4$ and Control), a Kruskal-Wallis non-parametric test were led and significant

237 differences between groups were indicated with letter (when letters are different, groups are

238 significantly different with a p value $<0.05$ ).

239 For the morphological and photosynthetic parameters, the statistical differences between the

240 value of the treated plants, either with the full concentration of sodium arsenite or one quarter

241 of it, and the one of the control plants were analyzed. According to the normality of the data

242 and the equality of the variances, the comparisons of the means two by two were performed

243 by Student's t-test if both normality and equality of variances were assumed, Aspin-Welch 's

244 test if there was no equality of variances and Mann-Whitney's test if the normality was not

245 assumed. Statistical tests were realized using R 3.3.3 software. Significant differences

246 between each treated condition and the corresponding controls are marked by $*$ at $\mathrm{p}<0.05$, **

247 at $\mathrm{p}<0.01$ and $* * * \mathrm{p}<0.001$.

\section{3. Results}

250 3.1. Concentration in total arsenic on grafted-plants 
Similar trends are reported in 2015 and 2016 (Figure 1, Table 2) for all the studied organs, i.e.

252

253

254 leaves, trunk and roots, and in the soil. Globally, the concentration of total arsenic was significantly higher in treated grafted-plant than in controls (Figure 1). We noted that naturally a small quantity of arsenic was detected in all the plant organs of the controls for both sampling times, less than $1 \mathrm{mg} / \mathrm{kg}$ of DW (less than $3 \mathrm{mg} / \mathrm{kg}$ of DW in the soil). From flowering to berry maturity, we observed a significant increase of total arsenic content especially in leaves $(\mathrm{p}<0.001)$ in 2015 and 2016. The average concentrations of arsenic increased from the leaves to the root system, with close to $10 \mathrm{mg} / \mathrm{kg}$ DW in leaves and 18 $\mathrm{mg} / \mathrm{kg}$ DW in roots at timepoint 6 months. In the soil, the average concentration of arsenic was higher than inside the plant and could reach $50 \mathrm{mg} / \mathrm{kg}$ DW 6 months after treatment. Similar trend was noted for the plants treated with $1 / 4$ rate of sodium arsenite, and the concentrations were intermediate between control and full sodium arsenite treated plants.

\subsection{Growth of grafted plants}

Control and treated plants expressed neither GTD foliar symptoms, nor of any other pests or diseases. In 2015, the treatment with sodium arsenite significantly affected the growth of the plants by decreasing the number, the length and the diameter of the green shoots especially at berry maturity (Table 3). Both the fresh weight and the volume of the root system tend to be lower for treated plants than for controls (Table 3). Similar trends were observed for plants sampled either at flowering or at berry maturity. In 2016, the treated plants showed also a global reduction of their growth but these differences were not significant at both flowering and berry maturity time (Table $2 \mathrm{~S}$ ). No specific alterations were observed on the growth of plants treated with $1 / 4$ rate of sodium arsenite.

\subsection{Photosynthesis measurements}

Gas exchange data for year 2015 are shown in Figure 2 and presented according to the number of days after the treatment date $(\mathrm{T}) . \mathrm{A}_{\mathrm{n}}$ was higher in control than treated plants from flowering, $\mathrm{T}+67$ days $\left(7.9 \mu \mathrm{mol} \mathrm{CO} \mathrm{CO}^{-2} \mathrm{~s}^{-1}\right.$ in controls and $5 \mu \mathrm{mol} \mathrm{CO} \mathrm{Cm}^{-2} \mathrm{~s}^{-1}$ in treated) to bunch closure, $\mathrm{T}+119$ days $\left(7.8 \mu \mathrm{mol} \mathrm{CO} \mathrm{m}^{-2} \mathrm{~s}^{-1}\right.$ in controls and $3.4 \mu \mathrm{mol} \mathrm{CO}_{2} \mathrm{~m}^{-2} \mathrm{~s}^{-1}$ in treated), and then, $A_{n}$ was higher in treated plants than in control until berry ripening $T+167$ days $\left(5.6 \mu \mathrm{mol} \mathrm{CO} 2 \mathrm{~m}^{-2} \mathrm{~s}^{-1}\right.$ in controls and $8.7 \mu \mathrm{mol} \mathrm{CO} \mathrm{CO}^{-2} \mathrm{~s}^{-1}$ in treated). Similar trend was observed for both $\mathrm{g}_{\mathrm{s}}$ and $\mathrm{E}$. Ci was either similar (at timepoints $\mathrm{T}+67, \mathrm{~T}+74, \mathrm{~T}+104, \mathrm{~T}+119$ days) or higher (at timepoints $\mathrm{T}+92, \mathrm{~T}+133, \mathrm{~T}+167$ days) in treated plants compared to controls. For $\phi$ PSII, the activity was lower in treated plants than in controls until bunch 
closure ( $T+133$ days) and then, similar to the controls to reach 0.6 at timepoint $T+167$ days.

286 Compared to the experiment in 2015, similar trends were observed in 2016 but the differences were less huge the for full treated plants compared to the controls (Table 3S). For the grafted plants treated by $1 / 4$ sodium arsenite concentration, no significant differences during the measurement series were reported compared to the controls except for $\mathrm{A}_{\mathrm{n}}, \mathrm{Ci}$ and WUE at T+130 days (Table 3S). $\phi$ PSII was not measured in 2016 since no relevant changes were noted in 2015.

\subsection{Molecular analysis}

In 2015 and at flowering, most of changes in treated plants consisted of the upregulation of SOD in leaves, CHV5 and STS in green stems and GST1, HSP $\alpha, C H V 5$ and STS in the root system (Table 4). In the green shoot, TIPl encoding for an aquaporin was down-regulated. At berry maturity, i.e. 6 months after the treatment with sodium arsenite, the pattern of expression is different with a repression of $H S P \alpha$ and an induction of TIPl in leaves (Table 4). In both green stem and roots, TIPl was also up-regulated. In the green stems only, GSTI and CHV5 were up-regulated and HSP $\alpha$ strongly down-regulated (Table 4). Compared to 2015, most of the induction of genes reported have been observed again in 2016 (Table 4S). We could note that for $H S P \alpha$, an inverse response in root at flowering and in leaves, green stems and root system at berry maturity was obtained. For the plants treated by $1 / 4$ rate of sodium arsenite, the pattern of the studied targeted genes is intermediate between the controls and plants full treated by sodium arsenite at both phenological stages (Table $4 \mathrm{~S}$ ).

\section{Discussion}

308 Our results confirmed that arsenic is translocated to all grapevine organs and accumulated in 309 the soil. It is important to acknowledge that the treatment was applied in winter, at the end of rest period, when the plant was dormant. The spray was applied until runoff and invariably

311 penetrated the soil. In our experiment, arsenic in the grafted Tempranillo has penetrated the

312 bark and accumulated in all organs from roots to leaves. The detection in leaves demonstrates 313 that arsenic moves through the plant via the vascular vessels. Many studies are concerned 314 with the translocation of arsenic from roots to both shoots and leaves and it appears that the main form of arsenic found in xylem sap is inorganic arsenite As(III) (see Zhao et al., 2009

316 for review). Except for leaves, total arsenic concentration in planta was similar at both 317 flowering and berry maturity stage probably because the grafted plants were in pots, a closed 
system with limited drainage. For comparison, Carbonell-Barrachina et al. (1997a) reported that low total arsenic quantity was detected in leaves and also in fruits and their quantity decreased during the vegetative cycle in both Aledo and Italia cultivars. In another crop such as rice, total arsenic concentrations decrease also markedly in the order of roots $>$ stems and leaves > fruit (Abedin et al., 2002; Liu et al., 2006; Xu et al., 2008). All the authors suggest that remobilization of arsenic from stems and leaves to other organs, if any, may be limited. Indeed, As(III) can form complexes with thiols like phytochelatins, which are sequestered in vacuoles, decreasing the As translocation (Raab et al., 2005). Moreover, efflux of arsenic to the soil from the root and vice versa could be involved. The high level of arsenic in the soil could result from the sodium arsenite treatment but also from the root exudation (Xu et al., 2007; Zhao et al., 2009 for review). Arsenic uptake pathway is well documented solely in rice by Ma et al. (2008). They reported that both Lsi1 and Lsi2 transporters were involved in influx and efflux of arsenic respectively. By the xylem vessels, a low quantity of arsenic is translocated in above-ground tissues and could be accumulated (Zhao et al., 2009; Quaghebeur and Rengel, 2004; Kofroñova et al., 2018).

The accumulation of arsenic alters the growth of the grafted plants especially the aerial organs. Compared to the controls, the grapevines treated with sodium arsenite showed a reduced growth in terms of the number, the length and the diameter of the green shoots especially at berry maturity. Amazingly, the development of the root system was affected by the treatment but not significantly. The root system inhibition could be correlated to the high concentration of arsenic detected in both the soil and the root system. The weak alteration of the root system could nevertheless have an impact on the development of the above-ground organs. Such reduction of the plant growth was reported in field crops (Jacobs et al., 1970), especially in tomato (Carbonell-Barrachina et al., 1994; Carbonell-Barrachina et al., 1995), in bean (Carbonel-Barrachina et al., 1997b) and in rice (Marin et al., 1992, Zhao et al., 2009, Rahman et al., 2007).

The reduction of the plant growth could be correlated to an alteration of the primary metabolism, especially the photosynthesis activity, due to the arsenic toxicity as reported by

348 Kofroñova et al. (2018). In the present study and especially in 2015 experiment, $A_{n}$ decreased 349 significantly in sodium arsenite treated grafted vines during the 4 months after treatment 350 ( $\mathrm{T}+119$ days). This decrease is correlated to a closure of stomata since $\mathrm{g}_{\mathrm{s}}$ is low. 
weak assimilation of the $\mathrm{CO}_{2}$ by the RuBisCo enzyme. Srivastava et al. (2013) reported also that arsenic stress affects negatively the photosynthesis activity in Hydrilla verticillate, an aquatic weed, $96 \mathrm{~h}$ after the treatment. The decrease of photosynthesis could be correlated to a decrease of photosynthetic pigments, chlorophyll-a and -b, as observed in Oryza sativa L. (Rahman et al., 2007). Six months after the sodium arsenite treatment, we observed inversely a significant increase of $A_{n}, g_{s}$ and $E$ with a later increase of Ci. $\phi$ PSII was firstly reduced in treated vines until $\mathrm{T}+119$ days suggesting a stress and then it was similar between treated and control plants as described for the gas exchanges parameters. In the meantime, the quantity of arsenic increased in leaves from flowering to berry ripening suggesting that the accumulation of arsenic may stimulate the photosynthesis over time. This induction of the photosynthesis appeared too late to stimulate the plant growth since at berry maturity the plants treated by sodium arsenite were always less developed compared to controls. The decrease of photoassimilates due to a low photosynthesis the first four months and the probable low level of sugar storage inside the young grafted plants used (3-year-old) could explained the limitation of the growth. Differences noted at 3 months between sodium arsenite treated and control plants for growth were maintained at 6 months. In grapevine, an alteration of the photosynthetic mechanism was already reported after treatments with chemicals such as fludioxonil and fenhexamid (Petit et al., 2009, 2012) and by copper or sulfur (Palmer et al., 2003; Xia et al., 2006). The photosynthesis thus appears to be a crucial hub point to regulate toxicity responses under chemical stress including As. In our study, the impact of As could also result in the activation of some processes of detoxification and stress tolerance that may induce its accumulation in vacuole (Zhao et al., 2009, Gusman et al., 2013). To illustrate, the lettuce plants are able to accumulate sodium arsenite in leaves but also to protect the photosynthetic apparatus against As, probably through the activation of tolerance mechanisms (Gusman et al., 2013).

In complement to the alteration of both growth and photosynthetic activity, some processes of detoxification could be induced in sodium arsenite treated plants compared to controls, as suggested by Farooq et al. $(2015,2016)$ and reviewed by Kofroñova et al. (2018). In both leaves and green stems, the antioxidant system was altered as suggested by the up-regulation firstly of $S O D$ at flowering, and then of GST1 at berry maturity. In the meantime, CHV5 encoding for a chitinase was up-regulated but only in green stem. For the root system, GST1,

384 CHV5 and STS were highly induced. All these strong inductions could be correlated to the higher level of arsenic content in roots and imply a reinforcement of stress tolerance 
mechanisms and detoxification in presence of arsenic. Moreover, an oxidative stress was perceived by the vine since $G S T 1$ were mainly up-regulated and $S O D$ up- or down-regulated according to the organs and the timepoint. For the antioxidant system, the enhanced activities of isoenzymes of superoxide dismutase, ascorbate peroxidase and glutathione reductase indicated that arsenic stress generates oxidative stress (Shri et al., 2009; Srivastava et al., 2013; Kumar et al., 2015 for review). Such plant responses to sodium arsenite were coupled with an antifungal growth activity correlated to both STS (Mazzullo et al., 2000; CoutosThévenot et al., 2001) and CHV5 (Mauch et al., 1988) inductions. In the roots, the aquaporine TIP1 was also activated but only at berry maturity. Aquaporins belonging to NIPs (nodulinglike intrinsic proteins) have the ability to transport multiple uncharged solutes including boric acid, salicylic acid (Wallace et al., 2006) as well as arsenic (Biernert et al., 2008, Ma et al., 2008). To date, it is supposed that some TIP channels may be permeable to arsenic and contribute to its transport in vacuole (Zhao et al., 2009). For the expression of $H S P \alpha$, encoding for a heat shock protein, it was inversely up- and down-regulated in the plants at flowering and berry maturity, respectively. At now, it is known that arsenic may induce specific proteins expression in response to abiotic stresses such as a heat shock. Saltveit et al. (2004) observed a similar proteomic pattern between a heat shock and an arsenic stress in cucumber radicles. All these perturbations under arsenic stress have also been reported for other heavy metals or fungicides (for review Petit et al., 2012). Comparing 2015 and 2016 experiments, the impact of a sodium arsenite treatment on plant physiology was globally the same. The alterations of the plant growth, the photosynthesis and the plant defense response in terms of detoxification process and stress tolerance were significantly higher in 2015 compared to 2016. Since the experiments were conducted under natural conditions, the weak differences between 2015 and 2016 could be explained by climatic conditions, slightly different between both years. The temperatures were thus globally lower in 2016 compared to 2015 while rainfall was higher (Figures 1S, 2S). Independently to the soil flushing that could result to the rainfalls, the evolution of the arsenic content in the soil from flowering to berry maturity are close in 2015 and 2016.

\section{Conclusion}

416 Until 2003 in Europe, sodium arsenite treatments were applied to control fungal diseases 417 especially against pathogens associated to trunk diebacks in grapevine. Since the ban of the 418 use of As, no similar efficient treatment is available to manage GTDs. The present study 419 concludes that arsenic was translocated to leaves, the photosynthesis was firstly reduced and 
420

421

422

423

424

425

426

427

428

429

430

431

432

433

434

435

436

437

438

439

440

441

442

443

444

445

446

447

448

449

450

451

then stimulated, and plant tolerance responses were induced including the antioxidant system. More in depth experiments focusing on arsenic stress on the plant microbiome may be required to know its global impact in the tripartite vine-GTDs pathogens-plant microbiome. The last step will be to identify a similar product for both plant and human health with the same efficacy as sodium arsenite to control GTDs by acting as a fungicide (Larignon et al., 2008) and plant elicitor as described herein.

\section{Acknowledgements}

The work included in the CASDAR V1301 project was funded by the French agriculture ministry and the interprofessional comity of vine in France (CNIV). We thank Richard Smart, a native English speaker and consultant in smart viticulture, for revising the English of this manuscript.

\section{References}

Abbas, G., Murtaza, B., Bibi, I., Shahid, M., Niazi, N. K., Khan, M. I., Amjad, M., Hussain, M., Natasha, 2018. Arsenic Uptake, Toxicity, Detoxification, and Speciation in Plants: Physiological, Biochemical, and Molecular Aspects. Int. J. Environ. Res. Public Health 15, 59-104. https://doi.org/10.3390/ijerph15010059.

Abedin, M.J., Feldmann, J., Meharg, A.A., 2002. Uptake kinetics of arsenic species in rice plants. Plant Physiol. 128, 1120-1128. https://doi.org/10.1104/pp.010733.

Bertsch, C., Ramírez-Suero, M., M., M. R., Larignon, P., Chong, J., Abou-Mansour, E., Fontaine, F., 2013. Grapevine trunk diseases: complex and still poorly understood. Plant Pathology, 62(2), 243-265. https://doi.org/10.1111/j.1365-3059.2012.02674

Bézier, A., Lambert, B., Baillieul, F., 2002. Study of defence-related gene expression in grapevine leaves and berries infected with Botrytis cinerea. Eur. J. Plant Pathol. 108: 111-120. https://doi.org/10.1023/A:1015061108045.

Bienert, G.P., Thorsen, M., Schüssler, M.D., Nilsson, H.R., Wagner, A., Tamás, M.J., Jahn, T.P., 2008. A subgroup of plant aquaporins facilitate the bi-directional diffusion of $\mathrm{As}(\mathrm{OH})_{3}$ and $\mathrm{Sb}(\mathrm{OH})_{3}$ across membranes. BMC Biol. 6, 26. https://doi.org/10.1186/1741-7007-6-26

Capus, J., Feytaud, J., 1909. L'eudémis et la cochylis en 1909. In: La Vigne Américaine et la Viticulture en Europe. 32 $2^{\text {ème }}$ année, nº 9 , septembre 1909, 276-278. 
Carbonell-Barrachina, A., Burlo Carbonell, F., Mataix Beneyto, J., 1994. Effect of arsenite on the concentrations of micro-nutrients in tomato plants grown in hydroponic culture. J. Plant Nut., 17, 1887-1903. https://doi.org/10.1080/01904169409364853.

Carbonell-Barrachina, A., Burlo-Carbonell, F., Mataix-Beneyto, J., 1995. Arsenic uptake, distribution, and accumulation in tomato plants: effect of arsenite on plant growth and yield. J. Plant. Nut., 18, 1237-1250. https://doi.org/10.1080/01904169509364975.

Carbonell-Barrachina, A., Burlo-Carbonell, F., Mataix-Beneyto, J., 1997a. Effect of sodium arsenite on arsenic accumulation and distribution in leaves and fruit of Vitis vinifera. J. Plant. Nut., 20, 379-387. https://doi.org/10.1080/01904169709365258.

Carbonell-Barrachina, A., Burlo-Carbonell, F., Mataix-Beneyto, J., 1997b. Effect of sodium arsenite and sodium chloride on bean plant nutrition (macronutrients). J. Plant. Nut., 20, 1617-1633. https://doi.org/10.1080/01904169709365361.

Chandrakar, V., Pandey, N., Keshavkant, S., 2018. Plant responses to arsenic toxicity: morphology and physiology, in: Hasanuzzaman, M., Nahar, K., Fujita, M. (Eds), Mechanisms of arsenic toxicity and tolerance in plants. Springer, Singapore, 2748.Chaumont, M., Morot-Gaudry, J. F., Foyer, C. H., 1994. Seasonal and diurnal changes in photosynthesis and carbon partitioning in Vitis vinifera leaves in vines with and without fruit. J. Exp. Bot. 45, 1235-1243. https://doi.org/10.1093/jxb/45.9.1235.

Coutos-Thévenot, P., Poinssot, B., Bonomelli, A., Yean, H., Breda, C., Buffard, D., Esnault, R., Hain, R., Boulay, M., 2001. In vitro tolerance to Botrytis cinerea of grapevine 41B rootstock in transgenic plants expressing the stilbene synthase Vst 1 gene under the control of a pathogen-inducible PR 10 promoter. J. Exp. Bot. 52, 901-910. https://doi.org/10.1093/jexbot/52.358.901.

Desaché, F., Courlit, Y., Ménard, E., 1995. Optimiser la lutte chimique contre l’Esca. Phytoma. 470, 29-31.

Epron, D., Dreyer, E., 1993. Long-term effects of drought on photosynthesis of adult oak trees (Quercus petraea (Matt.) Liebl. and Quercus robur L.) in a natural stand. New Phyt. 125, 381-389. https://doi.org/10.1111/j.1469-8137.1993.tb03890.x.

Farooq, M.A., Islam, F., Ali, B., Najeeb, U., Mao, B., Gill, R.A., Yan, G., Siddique, K.H.M., Zhou, W., 2016. Arsenic toxicity in plants: cellular and molecular mechanisms of its transport and metabolism. Environ. Exp. Bot. 132, 42-52. https://doi.org/10.1016/j.envexpbot.2016.08.004.

Farooq, M.A., Li, L., Ali, B., Gill, R.A., Wang, J., Ali, S, Gill, M.B., Zhou, W.J., 2015. Oxidative injury and antioxidant enzymes regulation in arsenic-exposed seedlings of 
four Brassica napus L. cultivars. Environ. Sci. Pollut. Res. 22, 10699-10712. https://doi.org/10.1007/s11356-015-4269-1.

Finnegan, P. M., Chen, W., 2012. Arsenic toxicity: the effects on plant metabolism. Front. Physiol. 3, 182. https://doi.org/10.3389/fphys.2012.00182.

Fontaine, F., Pinto, C., Vallet, J., Clément, C., Gomes, A.C., Spagnolo, A., 2015. The effects of grapevine trunk diseases (GTDs) on vine physiology. Eur J Plant Pathol 144:707-721. https://doi.org/10.1007/s10658-015-0770-0

Fontaine, F., Gramaje, D., Armengol, J., Smart, R., Nagy, Z. A., Borgo, M., Rego, C., CorioCostet, M. F., 2016. Grapevine Trunk Diseases. A review. COIV publications, 1st Edition (ISBN : 979-10-91799-60-7). Paris.

Grosjean, H., 1896. Rapport sur la destruction du silphe opaque par le vert de Scheele (arsénite de cuivre) en 1896. Bulletin du ministère de l'Agriculture. 346-351.

Gusman, G.S., Oliveira, J.A., Farnese, F.S., Cambraia, J., 2013. Arsenate and arsenite: the toxic effects on photosynthesis and growth of lettuce plants. Acta Physiol. Plant 35, 1201-1209. https://doi.org/10.1007/s11738-012-1159-8.

Hellemans, J., Mortier, G., De Paepe, A., Speleman, F., Vandesompele, J., 2007. QBase relative quantification framework and software for management and automated analysis of real-time quantitative PCR data. Genome Biol. 8, R19. https://doi.org/10.1186/gb2007-8-2-r19.

Hewitt, W.B., 1951. Grape dead-arm control. Plant Dis. Rep. 35, 142-143.

Hood, R.D., 1985. Cacodylic acid: agricultural uses, biologic effects, and environmental fate. Veterans administration central office department of medicine and surgery agent orange projects office washington, D.C. 171 pages.

Jacobs, L.W., Keeny, D.R., Walsh, L.M., 1970. Arsenic residue toxicity to vegetables crops grown on plain field sand. Agron. J. 62, 588-591. https://doi:10.2134/agronj1970.00021962006200050011x.

Kofroñova, M., Masková, P., Lipavská, H., 2018. Two facets of world arsenic problem solution: crop poisoning restriction and enforcement of phytoremediation. Planta 248: 19-35. https://doi.org/10.1007/s00425-018-2906-X

Kumar, S., Dubey, R.S., Tripathi, R.D., Chakrabarty, D., Trivedi, P.K., 2015. Omics and biotechnology of arsenic stress and detoxification in plants: current updates and prospective. Environ. Int. 74, 221-230. https://doi.org/10.1016/j.envint.2014.10.019.

Larignon, P., Darne, G., Menard, E., Desache, F., Dubos, B., 2008. Comment agissait l'arsénite de sodium sur l'Esca de la vigne ? Progr. Agric. Vitic., 125, 642-651. 
Latowski, D., Kowalczyk, A., Nawiesnial, K., Listwan, S., 2018. Arsenic uptake and transportation in plants, in: Hasanuzzaman, M., Nahar, K., Fujita, M. (Eds), Mechanisms of arsenic toxicity and tolerance in plants. Springer, Singapore, 1-26.

Li, N., Wang, J., Song, W.-Y., 2016. Arsenic uptake and translocation in plants. Plant Cell Physiol. 57, 4-13. https://doi.org/10.1093/pcp/pcv143.

Liu, W.J., Zhu, Y.G., Hu, Y., Williams, P.N., Gault, A.G., Meharg, A.A., Charnock, J.M., Smith, F.A., 2006. Arsenic sequestration in iron plaque, its accumulation and speciation in mature rice plants (Oryza sativa L.). Environ. Sci. Technol. 40, 5730-5736. https://doi.org/10.1021/es060800v.

Ma, J.F., Yamaji, N., Mitani, N., Xu, X.Y., Su, Y.H., McGrath, S.P., et al., 2008. Transporters of arsenite in rice and their role in arsenic accumulation in rice grain. Proc. Natl. Acad. Sci. U.S.A. 105, 9931-9935. https://doi.org/10.1073/pnas.0802361105.

Magnin-Robert, M., Letousey, P., Spagnolo, A., Rabenoelina, F., Jacquens, L., Mercier, L., Clément, C., Fontaine, F., 2011. Leaf strip of Esca induces alteration of photosynthesis and defence reactions in pre-symptomatic leaves. Funct. Plant Biol. 38, 856-866.

Magnin-Robert, M., Spagnolo, A., Dilezitoko, A., Cilindre, C., Mercier, L., Schaeffer-Reiss, C., Van Dorsselaer, A., Clément, C., Fontaine, F., 2014. Proteomic insights into changes in grapevine wood in response to Esca proper and apoplexy. Phytopathol. Mediterr. 53, 168-187. http://dx.doi.org/10.14601/Phytopathol_Mediterr-12913. Magnin-Robert, M., Adrian, M., Trouvelot, S., Spagnolo A., Jacquens, L., Letousey, P., Rabenoelina, F., Harir, M., Roullier-Gall, C., Clément, C., Schmitt-Kopplin, P., Vallat, A., Abou-Mansour, E., Fontaine, F., 2017. Alterations in grapevine leaf metabolism occur prior to Esca apoplexy appearance. Mol. Plant-Microbe Interact. 12, 946-959. https://doi.org/10.1094/MPMI-02-17-0036-R.

Marchal, P., 1919. La lutte hivernale contre la pyrale de la vigne par l'emploi des arsénicaux. Progrès Agricole et Viticole 72, 296-302.

Marin, A.R., Masscheleyn, P.H., Patrick Jr., W.H., 1992. The influence of chemical form and concentration of arsenic on rice growth and tissue arsenic concentration. Plant Soil 139, 175-183. https://doi.org/10.1007/BF00009308.

Mauch, F., Mauch-Mani, B., Boller, T., 1988. Antifungal hydrolases in pea tissue II. Inhibition of fungal growth by combinations of chitinase and beta-1, 3-glucanase. Plant Physiol. 88, 936-942. https://doi.org/10.1104/pp.88.3.936.

Mazzullo, A., Di Marco, S., Osti, F., Cesari, A., 2000. Bioassays on the activity of resveratrol, pterostilbene and phosphorous acid towards fungi associated with Esca of grapevine. 
Mondello, V., Songy, A., Battiston, E., Pinto, C., Coppin, C., Trotel-Aziz, P., Clément, C., Mugnai, L., Fontaine, F., 2018a. Grapevine trunk diseases: a review of fifteen years of trials for their control with chemicals and biocontrol agents. Plant Disease. 102, 11891217. https://doi.org/10.1094/PDIS-08-17-1181-FE.

Mondello, M., Larignon, P., Armengol, J., Kortekamp, A., Vaczy, K., Prezman, F., Serrano,

$$
\text { E., Rego, C., Mugnai, L., Fontaine, F., 2018b. Management of Grapevine Trunk }
$$
Europe. Phytopathol. Mediterr. 57(3), 369-383.

Mugnai, L., Graniti, A., Surico, G., 1999. Esca (black measles) and brown wood-streaking: two old and elusive diseases of grapevines. Plant Dis. 83, 404-417. https://doi.org/10.1094/PDIS.1999.83.5.404

Palmer, J.W., Davies, S.B., Shaw, P.W., Wünsche, J.N., 2003. Growth and fruit quality of 'Braeburn' apple (Malus domestica) trees as influenced by fungicide programmes suitable for organic production. New Zeal J Crop Hort Sci 31, 169-177. https://doi.org/10.1080/01140671.2003.9514249.

Petit, A.N., Fontaine, F., Clément, C., Vaillant-Gaveau, N., 2009. Gating in grapevine: relationship between application of the fungicide fludioxonil and circadian rhythm on photosynthesis. Environ. Pollut. 157, 130-134. https://doi.org/10.1016/j.envpol.2008.07.017.

Petit, A.N., Fontaine, F., Vasta, P., Clément, C., Vaillant-Gaveau, N., 2012. Fungicide impacts on photosynthesis in crops plants. Photosynthesis Research 111, 315-326. https://doi.org/10.1007/s11120-012-9719-8.

Quaghebeur, M., Rengel, Z., 2004. Arsenic uptake, translocation and speciation in phol and pho2 mutants of Arabidopsis thaliana. Physiol. Plant. 120, 280-286. https://doi.org/10.1111/j.0031-9317.2004.0240.x.

Quaintance, A.L., Scott, W.M., 1912. The most important insect and fungous enemies of the fruit and foliage of the apple. Farmer's Bulletin. $N^{\circ} 492.48$ pages.

Raab, A., Schat, H., Meharg, A.A., Feldmann, J., 2005. Uptake, translocation and transformation of arsenate and arsenite in sunflower (Helianthus annuus): formation of arsenic phytochelatin complexes during exposure to high arsenic concentrations. New Phytol. 168, 551-558.https://doi.org/10.1111/j.1469-8137.2005.01519.x. 
Rahman, M.A., Hasegawa, H., Rahman, M.M., Islam, M.N., Miah, M.A.M., Tasmen, A., 2007. Effect of arsenic on photosynthesis, growth and yield of five widely cultivated rice (Oryza sativa L.) varieties in Bangladesh. Chemosphere 67, 1072-1079. https://doi.org/10.1016/j.chemosphere.2006.11.061.

Ravaz, L., 1919. Encore l'apoplexie de la vigne. Prog. Agric. Vitic. 52, 601-603.

Ravaz, L., 1924. L'apoplexie de la vigne. Prog. Agric. Vitic. 81, 109-110.

Riley, C.V., 1876. Potato pests. Ed. New York Orange Judd Company. 108 pages.

Robinson, J.M., 1926. Dusting cotton with calcium arsenate for boll weevil control. Agricultural Experiment Station of the Alabama Polytechnic Institute, Auburn. Circular 51, May 1926.

Saltveit, M.E., Peiser, G., Rab, A., 2004. Effect of acetaldehyde, arsenite, ethanol, and heat shock on protein synthesis and chilling sensitivity of cucumber radicles. Physiol. Plant. 120, 556-562. https://doi.org/10.1111/j.1399-3054.2004.0280.x.

Santos, C., Fragoeiro, S., Oliveira, H., Phillips, A., 2006. Response of Vitis vinifera L. plant inoculated with Phaeoacremonium angustius and Phaeomoniella chlamydospora to thiabendazole, resveratrol and sodium arsenite. Sci. Hortic. 107, 131-136. https://doi.org/10.1016/j.scienta.2005.04.015.

Schultz, E.R., Thompson, N.F., 1925. Some effects of sodium arsenite when used to kill the common barberry. United States Department of Agriculture. In Cooperation with the University of Wisconsin and the Wisconsin Department of Agriculture. Department Bulletin $\mathrm{N}^{\circ} 1316,19$ pages.

Shri, M., Kumar, S., Chakrabarty, D., Trivedi, P.K., Mallick, S., Misra, P., Shukla, D., Srivatsava, S., Tripathi, R.D., Tuli, R., 2009. Effect of arsenic on growth, oxidative stress, and antioxidant system in rice seedlings. Ecotoxicol. Environ. Saf. 72, 11021110. https://doi.org/10.1016/j.ecoenv.2008.09.022.

Spagnolo, A., Magnin-Robert, M., Alayi, T.D., Cilindre, C., Mercier, L., Schaeffer-Reiss, C., Van Dorsselaer, A., Clément, C., Fontaine, F., 2012. Physiological changes in green stems of Vitis vinifera L. cv. Chardonnay in response to Esca proper and apoplexy revealed by proteomic and transcriptomic analyses. J. Proteome Res. 11, 461-475. https://doi.org/10.1021/pr200892g.

Spinosi, J., Févotte, J., Vial, G., 2009. Eléments techniques sur l'exposition professionnelle aux pesticides arsenicaux. Matrice cultures - expositions aux pesticides arsenicaux. Institut de veille sanitaire. Saint-Maurice, France, 19 pages. 
Srivastava, S., Mishra, S., Tripathi, R.D., Dwivedi, S., Trivedi, P.K., Tandon, P.K., 2007. Phytochelatins and antioxidant systems respond differentially during arsenite and arsenate stress in Hydrilla verticillata (Lf). Royle. Environ Sci Technol. 41, 2930-2936. https://doi.org/10.1021/es062167j.

Srivastava, S., Sharma, Y.K., 2013. Arsenic occurrence and accumulation in soil and water of eastern districts of Uttar Pradesh, India. Environ. Monit. Assess. 185, 4995-5002. https://doi.org/10.1007/s10661-012-2920-6.

Shri, M., Kumar, S., Chakrabarty, D., Trivedi, P.K., Mallick, S., Misra, P., Shukla, D., Mishra, S., Srivastava, Tripathi, R.D., Tuli, R., 2009. Effect of arsenic on growth, oxidative stress and antioxidant system in rice seedlings. Ecotox. Environ. Saf. 2, 1102-1110. https://doi.org/10.1016/j.ecoenv.2008.09.022.

Viala, P., 1926. Esca. Annales des Epiphyties. 180 pages.

Vidal, J.L., 1947. Les maladies de la vigne. Guy Le Prat Ed., Paris. 127 pages.

Vergnes, A., 1957. Sur les traitements de l'anthracnose maculée. Prog. Agric. Vitic. 147, 304309.

Wallace, I.S., Choi, W.G., Roberts, D. M., 2006. The structure, function and regulation of the nodulin 26-like intrinsic protein family of plant aquaglyceroporins. Biochim. Biophys. Acta Biomembr. 1758, 1165-1175. https://doi.org/10.1016/j.bbamem.2006.03.024.

Xia, X.J.; Huang, Y.Y.; Wang, L.; Huang, L.F.; Yu, Y.L.; Zhou, Y.H.; Yu, J.Q., 2006. Pesticides-induced depression of photosynthesis was alleviated by 24-epibrassinolide pretreatment in Cucumis sativus L. Pestic. Biochem. Physiol. 86, 42-48. https://doi.org/10.1016/i.pestbp.2006.01.005.

Xu, X.Y., McGrath, S.P., Zhao, F.J., 2007. Rapid reduction of arsenate in the medium mediated by plant roots. New Physiol. 176, 590-599. https://doi.org/10.1111/j.14698137.2007.02195.x.

Xu, X.Y., McGrath, S.P., Meharg, A., Zhao, F.J., 2008. Growing rice aerobically markedly decreases arsenic accumulation. Environ. Sci. Technol. 42, 5574-5577. https://doi.org/10.1021/es800324u.

Zhao, F.J., Ma, J.F., Meharg, A.A., McGrath, S.P., 2009. Arsenic uptake and metabolism in plants. New Phytol. 181, 777-794. https://doi.org/10.1111/j.1469-8137.2008.02716.x. 
654 Figure 1. Arsenic content in leaves, trunk below the graft/bud union, roots and soil on control 655 (T, black bars) and treated (A, gray bars) grafted-plants cv Tempranillo in 2016. Bar plain 656 corresponds to the samples collected at flowering and bar with white points to the samples 657 collected at berry maturity. Values \pm SD are represented on the graph. Significant differences 658 between control and treated plants for the different organs and for each collecting time are 659 marked by $*$ at $\mathrm{p}<0.05, * *$ at $\mathrm{p}<0.01$ and $* * *$ at $\mathrm{p}<0.001$.

660

661 Figure 2. Changes in A, net photosynthesis $\left(\mathrm{A}_{\mathrm{n}}\right) ; \mathrm{B}$, stomatal conductance $\left(\mathrm{g}_{\mathrm{s}}\right)$; C, internal leaf $662 \mathrm{CO}_{2}$ concentration $\left(\mathrm{C}_{\mathrm{i}}\right) ; \mathrm{D}$, transpiration $(\mathrm{E})$; E, photosystem II activity (ФPSII) and F, water 663 use efficiency (WUE) as $A_{n} / g_{s}$, measured in leaves of control (black squares) and treated 664 (grey squares) plant cv Tempranillo by sodium arsenite in 2015. Measurements were 665 performed at different dates from before the flowering, 67 days after the treatment with 666 sodium arsenite, to the berry maturity, 167 days after the treatment. The mean \pm SE was 667 calculated from 5 biological replicates. Significant differences between control and treated 668 plants are marked by $*$ at $\mathrm{p}<0.05, * *$ at $\mathrm{p}<0.01$ and $* * *$ at $\mathrm{p}<0.001$. 
687 Table 1. Primers of genes analyzed by real-time reverse-transcription polymerase chain 688 reaction. *TC TIGR: tentative consensus sequences

\begin{tabular}{|c|c|c|c|}
\hline Function & Gene & Primer Sequences & $\begin{array}{c}\text { GenBank or TC } \\
\text { TIGR Accession } \\
\text { Number } \\
\end{array}$ \\
\hline \multirow{6}{*}{$\begin{array}{l}\text { Housekeeping } \\
\text { genes }\end{array}$} & UBE2 & 5'-CATCCTTCAGGACAAGTGGT-3' & \multirow{2}{*}{ XM_002275879.1 } \\
\hline & (ubiquitin carrier protein E2) & 5'-GAGCTTTACAGATATACGAAACCG-3' & \\
\hline & \multirow{2}{*}{$\begin{array}{c}E F 1-\alpha \\
\text { (elongation factor } 1-\alpha)\end{array}$} & 5'-GAACTGGGTGCTTGATAGGC-3' & \multirow{2}{*}{ GU585871 } \\
\hline & & 5'-AACCAAAATATCCGGAGTAAAAGA-3' & \\
\hline & \multirow{2}{*}{$\begin{array}{c}60 S R P \\
\text { (60S ribosomal protein L18) }\end{array}$} & 5'-ATCTACCTCAAGCTCCTAGTC-3' & \multirow{2}{*}{ XM_002270599 } \\
\hline & & 5'-CAATCTTGTCCТССТTTCСТ-3' & \\
\hline \multirow{2}{*}{$\begin{array}{c}\text { Phenylpropanoid } \\
\text { metabolism }\end{array}$} & \multirow{2}{*}{$\begin{array}{c}\text { STS } \\
\text { (stilbene synthase) }\end{array}$} & 5'-AGGAAGCAGCATTGAAGGCTC-3' & \multirow{2}{*}{ FJ851185 } \\
\hline & & 5'-TGCACCAGGCATTTCTACACC-3' & \\
\hline \multirow{4}{*}{ Defense protein } & CHV5 & 5'-CTACAACTATGGCGCTGCTG-3' & \multirow{2}{*}{ AF532966 } \\
\hline & (class $\mathrm{V}$ chitinase) & 5'-CCAAAACCATAATGCGGTCT-3' & \\
\hline & PR1 & 5'-GGAGTCCATTAGCACTCCTTTG-3' & XM 0022737522 \\
\hline & (pathogenesis-related protein 1 ) & 5'-CATAATTCTGGGCGTAGGCAG-3' & \\
\hline \multirow{6}{*}{$\begin{array}{l}\text { Detoxification } \\
\text { and stress } \\
\text { tolerance }\end{array}$} & GST1 & 5'-TGCATGGAGGAGGAGTTCGT-3' & \multirow{2}{*}{ AY156048 } \\
\hline & (glutathion-S-transferase 1) & 5'-CAAGGCTATATCCCCATTTTCTTC-3' & \\
\hline & \multirow{2}{*}{$\begin{array}{c}H S P \alpha \\
\text { (alpha crystalline heat shock } \\
\text { protein) }\end{array}$} & 5'-TCGGTGGAGGATGACTTGCT-3' & \multirow{2}{*}{ XM_002272382 } \\
\hline & & 5'-CGTGTGCTGTACGAGCTGAAG-3' & \\
\hline & \multirow{2}{*}{$\begin{array}{c}S O D \\
\text { (superoxide dismutase) } \\
\end{array}$} & 5'-GTGGACCTAATGCAGTGATTGGA-3' & \multirow{2}{*}{ AF056622 } \\
\hline & & 5'-TGCCAGTGGTAAGGCTAAGTTCA-3' & \\
\hline \multirow{2}{*}{ Water stress } & TIP1 & 5'-ATCACCAACСТCATTCATATGC-3' & \multirow{2}{*}{ AF271661 } \\
\hline & (tonoplast intrinsic aquaporin) & 5'-GTTGTTGTCTCAACCCATTTCC-3' & \\
\hline
\end{tabular}

689

690

691 
693 Table 2. Arsenic contents (mean value \pm SD) in $\mathrm{mg} / \mathrm{kg}$ DW measured in 2015 and 2016 in 694 leaves, trunk below the graft/bud union, roots and soil of the grafted grapevine cv. 695 Tempranillo untreated (C) and treated (full, As and one quarter of the prior application rate, 696 As 1/4). Significant differences between the three modalities (As, As 1/4 and C) for each area 697 are indicated by letters (if letters are different, the difference between groups are significant). 698 Nd: not determined.

699

\begin{tabular}{|c|c|c|c|c|c|c|c|c|c|c|c|c|c|}
\hline & & \multicolumn{3}{|c|}{ Leaves } & \multicolumn{3}{|c|}{ Trunk } & \multicolumn{3}{|c|}{ Roots } & \multicolumn{3}{|c|}{ Soil } \\
\hline & & $\mathbf{C}$ & As 1/4 & As & $\mathbf{C}$ & As 1/4 & As & $\mathbf{C}$ & As 1/4 & As & $\mathbf{C}$ & As 1/4 & As \\
\hline \multirow{4}{*}{ ฮั่ } & Flowering (mean) & $\begin{array}{c}0.01 \\
\mathrm{a}\end{array}$ & $\begin{array}{c}0.91 \\
\mathrm{~b}\end{array}$ & $\begin{array}{c}2.35 \\
\mathrm{c}\end{array}$ & $\begin{array}{c}0.48 \\
\mathrm{a}\end{array}$ & $\begin{array}{c}1.72 \\
b\end{array}$ & $\begin{array}{c}3.94 \\
\mathrm{~b}\end{array}$ & \begin{tabular}{|c|}
0.54 \\
$\mathrm{a}$ \\
\end{tabular} & $\begin{array}{c}5.15 \\
\mathrm{~b}\end{array}$ & $\begin{array}{c}10.44 \\
\mathrm{c}\end{array}$ & $\begin{array}{c}1.22 \\
\mathrm{a}\end{array}$ & $\begin{array}{c}7.17 \\
b\end{array}$ & $\begin{array}{c}15.62 \\
\mathrm{c}\end{array}$ \\
\hline & Flowering SD & 0.00 & 0.40 & 0.68 & 0.20 & 0.64 & 1.81 & 0.18 & 3.35 & 4.27 & 0.23 & 3.48 & 5.97 \\
\hline & Berry maturity (mean) & $\begin{array}{c}0.19 \\
\mathrm{a} \\
\end{array}$ & $\begin{array}{c}5.26 \\
\mathrm{~b} \\
\end{array}$ & $\begin{array}{c}9.00 \\
\mathrm{c} \\
\end{array}$ & $\begin{array}{c}0.43 \\
\mathrm{a} \\
\end{array}$ & $\begin{array}{c}3.25 \\
\mathrm{~b} \\
\end{array}$ & $\begin{array}{c}7.46 \\
\mathrm{c} \\
\end{array}$ & \begin{tabular}{|c|}
0.60 \\
$\mathrm{a}$ \\
\end{tabular} & $\begin{array}{c}5.02 \\
\mathrm{~b} \\
\end{array}$ & $\begin{array}{c}14.35 \\
\mathrm{c} \\
\end{array}$ & $\begin{array}{c}1.48 \\
\mathrm{a} \\
\end{array}$ & $\begin{array}{c}19.64 \\
\mathrm{~b} \\
\end{array}$ & $\begin{array}{c}33.75 \\
\mathrm{~b} \\
\end{array}$ \\
\hline & Berry maturity SD & 0.12 & 1.20 & 1.76 & 0.17 & 1.91 & 3.31 & 0.23 & 1.45 & 9.29 & 0.64 & 12.85 & 31.01 \\
\hline \multirow{2}{*}{$\stackrel{n}{\bar{\nu}}$} & Flowering (mean) & $\begin{array}{c}0.12 \\
\mathrm{a} \\
\end{array}$ & nd & $\begin{array}{c}3.42 \\
\mathrm{~b}\end{array}$ & nd & nd & nd & $\begin{array}{c}0.48 \\
\mathrm{a} \\
\end{array}$ & nd & $\begin{array}{c}9.80 \\
\mathrm{~b} \\
\end{array}$ & nd & nd & nd \\
\hline & Flowering SD & 0.00 & nd & 0.64 & nd & nd & nd & 0.02 & nd & 1.27 & nd & nd & nd \\
\hline
\end{tabular}


Table 3. Growth parameters of the grafted grapevine cv. Tempranillo untreated (Control) and treated by sodium arsenite (Treated) measured at flowering and at berry maturity in 2015 . Values are means \pm SE of 5 biological replicates. Significant differences between each treated condition and the controls are marked by $*$ at $\mathrm{p}<0.05, * *$ at $\mathrm{p}<0.01, * * *$ at $\mathrm{p}<0.001$.

\begin{tabular}{|l|c|c|c|c|}
\cline { 2 - 5 } & \multicolumn{2}{c|}{ Flowering } & \multicolumn{2}{c|}{ Berry maturity } \\
\cline { 2 - 5 } & Control & Treated & Control & Treated \\
\hline Number of green shoots & $3.00 \pm 0.45$ & $2.00 \pm 0.32$ & $4.20 \pm 0.37$ & $2.40 \pm 0.40^{*}$ \\
\hline Length of green shoots $(\mathrm{cm})$ & $35.60 \pm 1.03$ & $12.60 \pm 3.86^{* *}$ & $50.30 \pm 4.31$ & $26.00 \pm 5.82^{*}$ \\
\hline Diameter of green shoots $(\mathrm{cm})$ & $0.81 \pm 0.04$ & $0.60 \pm 0.04 * *$ & $0.80 \pm 0.05$ & $0.51 \pm 0.03 * *$ \\
\hline Fresh weight of root system $(\mathrm{g})$ & $209.08 \pm 43.54$ & $168.67 \pm 36.59$ & $318.73 \pm 50.01$ & $286.86 \pm 30.38$ \\
\hline Volume of root system $\left(\mathrm{cm}^{3}\right)$ & $216.78 \pm 42.10$ & $163.58 \pm 30.28$ & $366.83 \pm 45.86$ & $278.70 \pm 34.03$ \\
\hline
\end{tabular}

706

707

708

709

Table 4. Relative expression levels of the 6 selected genes recorded by RT-qPCR in leaves, green stems and roots of grafted grapevines cv. Tempranillo treated with sodium arsenite at flowering and at berry maturity in 2015, i.e. 90 and 183 after the treatment respectively. Values correspond to the means \pm SE of 5 biological replicates. Gene expression of untreated plant (control) was used as reference to calculate relative expression. A given gene was considered up- or down-regulated when the value of relative expression was $>2$-fold or $<0.5$ fold compared to the controls, respectively. Genes down- or over-expressed appear in shades of grey, with expression levels lower or higher than 0.1 and 30, respectively, in dark grey. In white, there is no change in gene expression compared to the controls. nd: not determined; ne: not expressed.

\begin{tabular}{|l|c|c|c|c|c|c|}
\cline { 2 - 7 } \multicolumn{1}{c|}{} & \multicolumn{3}{c|}{ Flowering } & \multicolumn{3}{c|}{ Berry maturity } \\
\cline { 2 - 7 } \multicolumn{1}{c|}{} & Leaves & Green stems & Roots & Leaves & Green stems & Roots \\
\hline GST1 & ne & ne & $64.95 \pm 19.81$ & $21.03 \pm 2.86$ & $6.25 \pm 2.72$ & $6.90 \pm 2.90$ \\
\hline$S O D$ & $26.86 \pm 2.04$ & $2.7 \pm 0.19$ & $1.03 \pm 0.06$ & $0.63 \pm 0.13$ & $0.97 \pm 0.05$ & $1.09 \pm 0.21$ \\
\hline$H S P \alpha$ & $2.63 \pm 0.40$ & $0.73 \pm 0.10$ & $3.28 \pm 0.73$ & $0.29 \pm 0.00$ & $0.08 \pm 0.02$ & $0.42 \pm 0.12$ \\
\hline CHV5 & $0.56 \pm 0.16$ & $4.18 \pm 2.23$ & $9.79 \pm 3.95$ & $0.60 \pm 0.14$ & $16.96 \pm 7.23$ & $6.32 \pm 2.25$ \\
\hline STS & nd & $4.59 \pm 1.27$ & $5.47 \pm 1.77$ & nd & $1.3 \pm 0.41$ & $2.04 \pm 0.69$ \\
\hline TIP1 & $0.52 \pm 0.10$ & $0.28 \pm 0.01$ & $0.83 \pm 0.11$ & $2.43 \pm 0.22$ & $2.01 \pm 0.14$ & $7.26 \pm 0.67$ \\
\hline
\end{tabular}

$\leq 0.1 \quad 0.5 \quad 2$

$+2$


Supplementary material

726 Table 1S. ICP-MS operating parameters

\begin{tabular}{|l|l|}
\hline RF Power & $1550 \mathrm{~W}$ \\
\hline Carrier gas & $0.9 \mathrm{Lmin}^{-1}$ \\
\hline Make-up gas & $0.21 \mathrm{~L} \mathrm{~min}^{-1}$ \\
\hline Collision gas & $\mathrm{He}\left(5 \mathrm{~mL} \mathrm{~min} \mathrm{~min}^{-1}\right)$ \\
\hline Spray chamber temperature & $2^{\circ} \mathrm{C}$ \\
\hline Detector mode & Pulse Counting \\
\hline Integration time & $0.3 \mathrm{~s}$ \\
\hline
\end{tabular}

Table 2S. Growth parameters of the grafted grapevine cv. Tempranillo untreated (Control) replicates. Significant differences between each treated condition and the controls are marked by $*$ at $\mathrm{p}<0.05, * *$ at $\mathrm{p}<0.01, * * *$ at $\mathrm{p}<0.001$.

\begin{tabular}{|l|c|c|c|c|c|c|}
\cline { 2 - 7 } \multicolumn{1}{c|}{} & \multicolumn{3}{c|}{ Flowering } & \multicolumn{3}{c|}{ Berry maturity } \\
\cline { 2 - 7 } \multicolumn{1}{c|}{} & Control & As $1 / 4$ & As & Control & As 1/4 & As \\
\hline $\begin{array}{l}\text { Number of green } \\
\text { shoots }\end{array}$ & $4.40 \pm 0.48$ & $\begin{array}{c}2.90 \pm \\
0.41^{*}\end{array}$ & $\begin{array}{c}2.90 \pm \\
0.23^{*}\end{array}$ & $3.20 \pm 0.29$ & $\begin{array}{c}2.40 \pm \\
0.22^{*}\end{array}$ & $2.70 \pm 0.21$ \\
\hline $\begin{array}{l}\text { Length of green } \\
\text { shoots (cm) }\end{array}$ & $37.31 \pm 3.12$ & $\begin{array}{c}39.86 \pm \\
3.25\end{array}$ & $\begin{array}{c}30.27 \pm \\
4.57\end{array}$ & $50.03 \pm 5.56$ & $\begin{array}{c}47.13 \pm \\
4.48\end{array}$ & $32.80 \pm$ \\
\hline $\begin{array}{l}\text { Diameter of green } \\
\text { shoots (cm) }\end{array}$ & $0.47 \pm 0.02$ & $0.47 \pm 0.02$ & $0.43 \pm 0.03$ & $0.55 \pm 0.03$ & $0.54 \pm 0.02$ & $0.47 \pm 0.03$ \\
\hline $\begin{array}{l}\text { Fresh weight of } \\
\text { root system (g) }\end{array}$ & $203.53 \pm$ & $207.30 \pm$ & $199.36 \pm$ & $192.69 \pm$ & $179.87 \pm$ & $224.72 \pm$ \\
\hline $\begin{array}{l}\text { Volume of root } \\
\text { system }\left(\mathrm{cm}^{3}\right)\end{array}$ & 24.14 & 24.07 & 23.58 & 22.57 & 36.71 & 29.08 \\
\hline
\end{tabular}


735 Table $3 \mathrm{~S}$. Changes in net photosynthesis $\left(\mathrm{A}_{\mathrm{n}}\right)$, stomatal conductance $\left(\mathrm{g}_{\mathrm{s}}\right)$, internal leaf $\mathrm{CO}_{2}$ 736 concentration $\left(\mathrm{C}_{\mathrm{i}}\right)$, transpiration (E) and water use efficiency (WUE) as $\mathrm{A}_{\mathrm{n}} / \mathrm{g}_{\mathrm{s}}$ measured in 737 leaves of grafted grapevine cv. Tempranillo untreated (Control) or treated by sodium arsenite 738 in 2016 (full, As and one quarter of the prior application rate, As 1/4). The mean \pm SE was 739 calculated from 10 biological replicates at different dates from before the flowering, 96 days 740 after the treatment with sodium arsenite, to the berry maturity, 157 days after the treatment 741 date. Significant differences between each treated conditions and the controls are marked by * 742 at $\mathrm{p}<0.05, * *$ at $\mathrm{p}<0.01, * * *$ at $\mathrm{p}<0.001$.

\begin{tabular}{|c|c|c|c|}
\hline $\begin{array}{l}\text { Days post } \\
\text { treatment }\end{array}$ & Control & As 1/4 & As \\
\hline & \multicolumn{3}{|c|}{$\mathbf{A}_{\mathbf{n}}\left(\mu \mathrm{mol} \mathrm{CO} \mathrm{CO}_{2} \mathrm{~m}^{-2} \mathrm{~s}^{-1}\right)$} \\
\hline 96 & $6.34 \pm 0.30$ & $6.49 \pm 0.24$ & $5.69 \pm 0.15 *$ \\
\hline 109 & $5.38 \pm 0.23$ & $5.66 \pm 0.27$ & $5.59 \pm 0.38$ \\
\hline 130 & $2.86 \pm 0.36$ & $4.19 \pm 0.55 *$ & $2.99 \pm 0.25$ \\
\hline 136 & $4.59 \pm 0.49$ & $4.54 \pm 0.34$ & $4.28 \pm 0.43$ \\
\hline \multirow[t]{2}{*}{157} & $3.45 \pm 0.43$ & $3.77 \pm 0.43$ & $3.09 \pm 0.54$ \\
\hline & \multicolumn{3}{|c|}{$\mathbf{g}_{\mathbf{s}}\left(\mathrm{mol} \mathrm{H}_{2} \mathrm{O} \mathrm{m}^{-2} \mathrm{~s}^{-1}\right)$} \\
\hline 96 & $0.13 \pm 0.01$ & $0.14 \pm 0.01$ & $0.09 \pm 0.01 * * *$ \\
\hline 109 & $0.11 \pm 0.02$ & $0.14 \pm 0.01$ & $0.10 \pm 0.01$ \\
\hline 130 & $0.05 \pm 0.00$ & $0.06 \pm 0.01$ & $0.03 \pm 0.00 * *$ \\
\hline 136 & $0.08 \pm 0.01$ & $0.10 \pm 0.01$ & $0.07 \pm 0.01$ \\
\hline \multirow[t]{2}{*}{157} & $0.08 \pm 0.01$ & $0.09 \pm 0.01$ & $0.07 \pm 0.01$ \\
\hline & \multicolumn{3}{|c|}{$\mathbf{C i}\left(\mu \mathrm{mol} \mathrm{CO} \mathrm{mol}^{-1}\right)$} \\
\hline 96 & $292.22 \pm 2.11$ & $291.58 \pm 4.01$ & $246.70 \pm 17.03 *$ \\
\hline 109 & $261.18 \pm 29.56$ & $302.28 \pm 3.96$ & $275.06 \pm 7.94$ \\
\hline 130 & $280.27 \pm 11.37$ & $246.54 \pm 11.71 *$ & $203.83 \pm 17.31 * *$ \\
\hline 136 & $279.36 \pm 4.47$ & $290.68 \pm 6.11$ & $264.85 \pm 9.91$ \\
\hline \multirow[t]{2}{*}{157} & $303.10 \pm 9.93$ & $294.94 \pm 5.83$ & $297.15 \pm 7.28$ \\
\hline & \multicolumn{3}{|c|}{$\mathbf{E}\left(\mathrm{mmol} \mathrm{H} \mathrm{H}_{2} \mathrm{O}^{-2} \mathrm{~s}^{-1}\right)$} \\
\hline 96 & $1.64 \pm 0.08$ & $1.55 \pm 0.09$ & $1.18 \pm 0.11 * *$ \\
\hline 109 & $1.40 \pm 0.14$ & $1.65 \pm 0.11$ & $1.30 \pm 0.08$ \\
\hline 130 & $0.97 \pm 0.08$ & $1.22 \pm 0.13$ & $0.73 \pm 0.06 *$ \\
\hline 136 & $1.21 \pm 0.11$ & $1.50 \pm 0.10 *$ & $1.16 \pm 0.12$ \\
\hline \multirow[t]{2}{*}{157} & $1.32 \pm 0.16$ & $1.65 \pm 0.14$ & $1.23 \pm 0.22$ \\
\hline & \multicolumn{3}{|c|}{ WUE $\left(\mu \mathrm{mol} \mathrm{CO}_{2} \mathrm{~mol}^{-1} \mathrm{H}_{2} \mathrm{O}\right)$} \\
\hline 96 & $48.96 \pm 1.28$ & $48.83 \pm 2.12$ & $77.46 \pm 10.83 * *$ \\
\hline 109 & $52.29 \pm 3.65$ & $43.83 \pm 2.49 *$ & $60.56 \pm 4.96$ \\
\hline 130 & $55.71 \pm 7.16$ & $76.45 \pm 7.39 *$ & $103.22 \pm 10.97 * *$ \\
\hline 136 & $57.37 \pm 2.80$ & $50.08 \pm 3.87$ & $66.12 \pm 6.26$ \\
\hline 157 & $41.97 \pm 6.17$ & $46.04 \pm 3.66$ & $44.83 \pm 4.81$ \\
\hline
\end{tabular}


748 Table 4S. Relative expression levels of the 6 selected genes recorded by RT-qPCR in leaves,

749 green stems and roots of grafted grapevines cv. Tempranillo treated with sodium arsenite (full,

750 As and one quarter of the prior application rate, As 1/4) at flowering and at berry maturity in

7512016 , i.e. 64 and 188 after the treatment respectively. Values correspond to the means \pm SE of

75210 biological replicates. Gene expression of untreated plant (control) was used as reference to

753 calculate relative gene expression for the treated plant (As and As $1 / 4$ ). A given gene was

754 considered up- or down-regulated when the value of relative expression was $>2$-fold or $<0.5$ -

755 fold compared to the control, respectively. Genes down- or over-expressed appear in shades

756 of grey, with expression levels lower or higher than 0.1 and 30, respectively, in dark grey. In

757 white, there is no change in gene expression compared to the control. ND: not determined.

\begin{tabular}{|c|c|c|c|c|c|c|c|c|c|c|c|c|}
\hline & \multicolumn{6}{|c|}{ Flowering } & \multicolumn{6}{|c|}{ Berry maturity } \\
\hline & \multicolumn{2}{|c|}{ Leaves } & \multicolumn{2}{|c|}{ Green stems } & \multicolumn{2}{|c|}{ Roots } & \multicolumn{2}{|c|}{ Leaves } & \multicolumn{2}{|c|}{ Green stems } & \multicolumn{2}{|c|}{ Roots } \\
\hline & As & $\mathrm{As}^{1 / 4}$ & As & $\mathrm{As}^{1} / 4$ & As & $\mathrm{As} 1 / 4$ & As & $\mathrm{As} 1 / 4$ & As & $\mathrm{As}^{1} / 4$ & As & $\mathrm{As}^{1 / 4}$ \\
\hline GST1 & $\begin{array}{c}1.53 \pm \\
0.12\end{array}$ & $\begin{array}{c}1.09 \pm \\
0.37\end{array}$ & $\begin{array}{c}3.38 \pm \\
0.59\end{array}$ & $\begin{array}{c}1.00 \pm \\
0.17\end{array}$ & $\begin{array}{c}8.60 \pm \\
3.40 \\
\end{array}$ & $\begin{array}{c}6.18 \pm \\
2.04 \\
\end{array}$ & $\begin{array}{c}6.22 \pm \\
1.67 \\
\end{array}$ & $\begin{array}{c}2.56 \pm \\
0.45\end{array}$ & $\begin{array}{c}0.35 \pm \\
0.08\end{array}$ & $\begin{array}{c}1.87 \pm \\
0.55\end{array}$ & $\begin{array}{c}0.81 \pm \\
0.44\end{array}$ & $\begin{array}{c}1.69 \pm \\
0.33\end{array}$ \\
\hline$S O D$ & $\begin{array}{c}0.90 \pm \\
0.12\end{array}$ & $\begin{array}{c}2.36 \pm \\
0.21 \\
\end{array}$ & $\begin{array}{c}1.39 \pm \\
0.07\end{array}$ & $\begin{array}{c}1.22 \pm \\
0.08\end{array}$ & $\begin{array}{c}0.77 \pm \\
0.10 \\
\end{array}$ & $\begin{array}{c}1.06 \pm \\
0.22\end{array}$ & $\begin{array}{c}1.11 \pm \\
0.15\end{array}$ & $\begin{array}{c}0.67 \pm \\
0.08 \\
\end{array}$ & $\begin{array}{c}1.05 \pm \\
0.10\end{array}$ & $\begin{array}{c}0.83 \pm \\
0.04\end{array}$ & $\begin{array}{c}0.57 \pm \\
0.18 \\
\end{array}$ & $\begin{array}{c}0.50 \pm \\
0.02\end{array}$ \\
\hline$H S P \alpha$ & $\begin{array}{c}9.51 \pm \\
3.19 \\
\end{array}$ & $\begin{array}{c}2.91 \pm \\
0.58 \\
\end{array}$ & $\begin{array}{c}1.41 \pm \\
0.10\end{array}$ & $\begin{array}{c}1.73 \pm \\
0.26 \\
\end{array}$ & $\begin{array}{c}0.26 \pm \\
0.10 \\
\end{array}$ & $\begin{array}{c}0.45 \pm \\
0.06\end{array}$ & $\begin{array}{c}72.23 \pm \\
8.46 \\
\end{array}$ & $\begin{array}{c}1.16 \pm \\
0.21 \\
\end{array}$ & $\begin{array}{c}11.22 \pm \\
4.39 \\
\end{array}$ & $\begin{array}{c}1.45 \pm \\
0.35\end{array}$ & $\begin{array}{c}17.75 \pm \\
5.15 \\
\end{array}$ & $\begin{array}{c}40.73 \pm \\
0.41 \\
\end{array}$ \\
\hline CHV5 & $\begin{array}{c}0.73 \pm \\
0.06 \\
\end{array}$ & $\begin{array}{c}0.85 \pm \\
0.05 \\
\end{array}$ & $\begin{array}{c}1.11 \pm \\
0.26 \\
\end{array}$ & $\begin{array}{c}0.64 \pm \\
0.09 \\
\end{array}$ & $\begin{array}{c}3.53 \pm \\
0.51 \\
\end{array}$ & $\begin{array}{c}1.80 \pm \\
0.41 \\
\end{array}$ & $\begin{array}{c}2.17 \pm \\
0.53 \\
\end{array}$ & $\begin{array}{c}3.37 \pm \\
0.47 \\
\end{array}$ & $\begin{array}{c}0.75 \pm \\
0.14 \\
\end{array}$ & $\begin{array}{c}0.86 \pm \\
0.18 \\
\end{array}$ & $\begin{array}{c}2.94 \pm \\
0.46 \\
\end{array}$ & $\begin{array}{c}1.95 \pm \\
0.45 \\
\end{array}$ \\
\hline STS & $\begin{array}{c}0.92 \pm \\
0.07 \\
\end{array}$ & $\begin{array}{c}0.58 \pm \\
0.13 \\
\end{array}$ & $\begin{array}{c}3.77 \pm \\
0.72 \\
\end{array}$ & $\begin{array}{c}0.55 \pm \\
0.08 \\
\end{array}$ & $\begin{array}{c}2.12 \pm \\
0.62 \\
\end{array}$ & $\begin{array}{c}1.26 \pm \\
0.23\end{array}$ & ND & ND & $\begin{array}{c}0.59 \pm \\
0.13 \\
\end{array}$ & $\begin{array}{c}0.78 \pm \\
0.17 \\
\end{array}$ & $\begin{array}{c}0.75 \pm \\
0.13\end{array}$ & $\begin{array}{c}2.62 \pm \\
0.59 \\
\end{array}$ \\
\hline PRl & $\begin{array}{c}0.46 \pm \\
0.10\end{array}$ & $\begin{array}{c}1.30 \pm \\
0.16\end{array}$ & $\begin{array}{c}1.19 \pm \\
0.32\end{array}$ & $\begin{array}{c}2.43 \pm \\
0.32 \\
\end{array}$ & $\begin{array}{c}2.31 \pm \\
1.17 \\
\end{array}$ & $\begin{array}{c}2.95 \pm \\
0.73\end{array}$ & $\begin{array}{c}1.50 \pm \\
0.19\end{array}$ & $\begin{array}{c}2.68 \pm \\
0.27 \\
\end{array}$ & $\begin{array}{c}0.39 \pm \\
0.12\end{array}$ & $\begin{array}{c}0.48 \pm \\
0.12\end{array}$ & $\begin{array}{c}0.07 \pm \\
0.02 \\
\end{array}$ & $\begin{array}{c}0.28 \pm \\
0.07\end{array}$ \\
\hline
\end{tabular}


Figure 1.

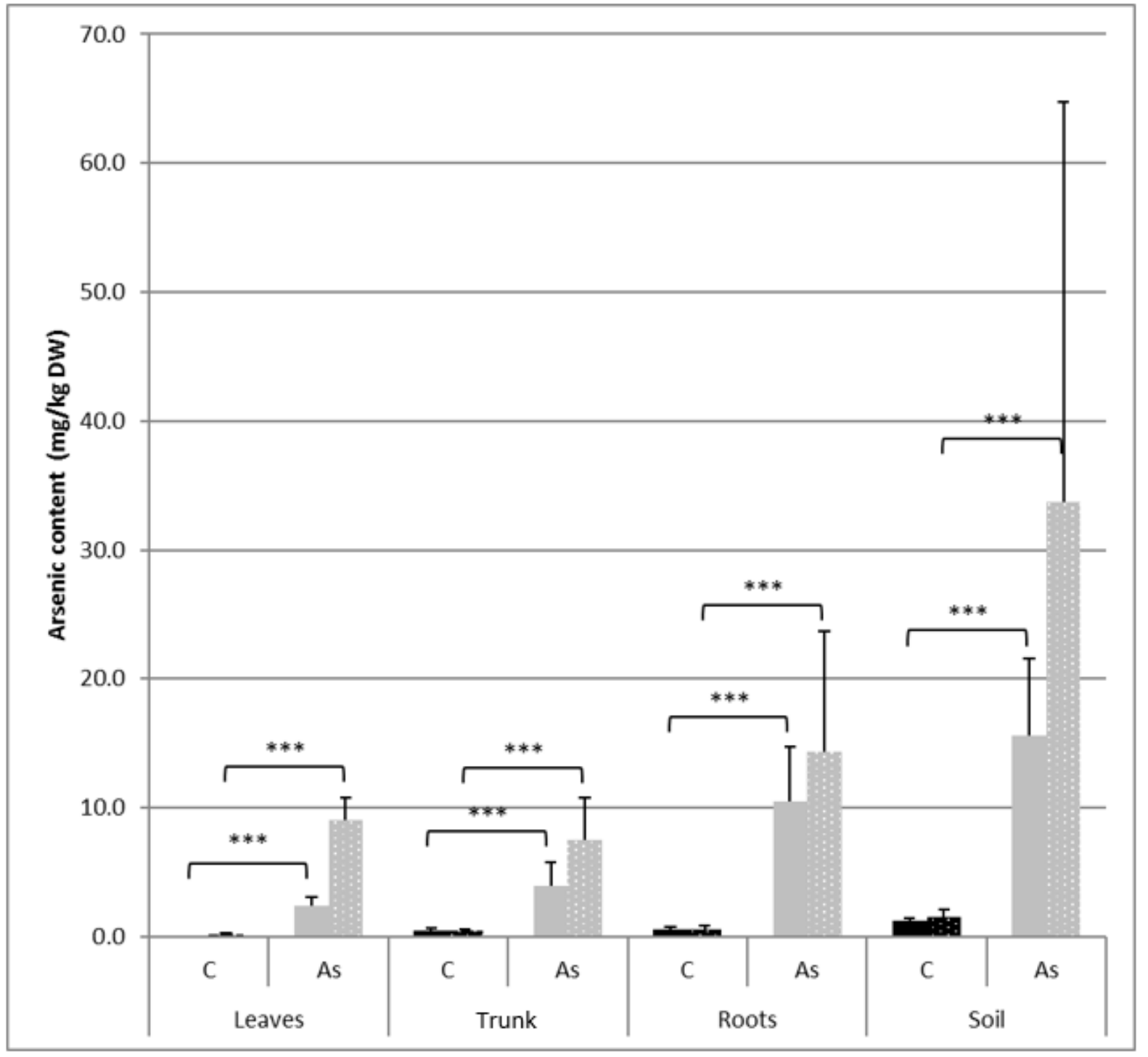


Figure 2.

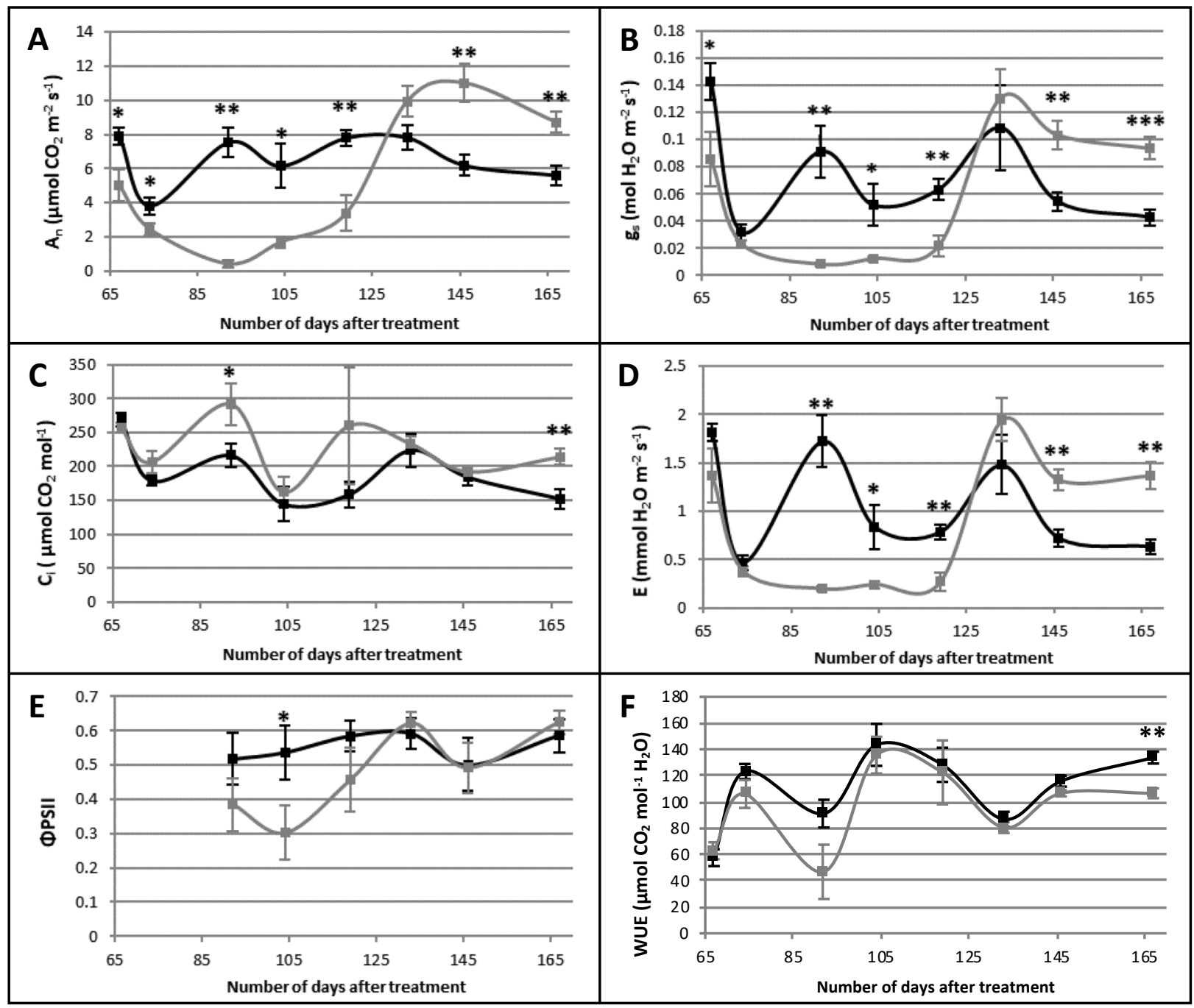




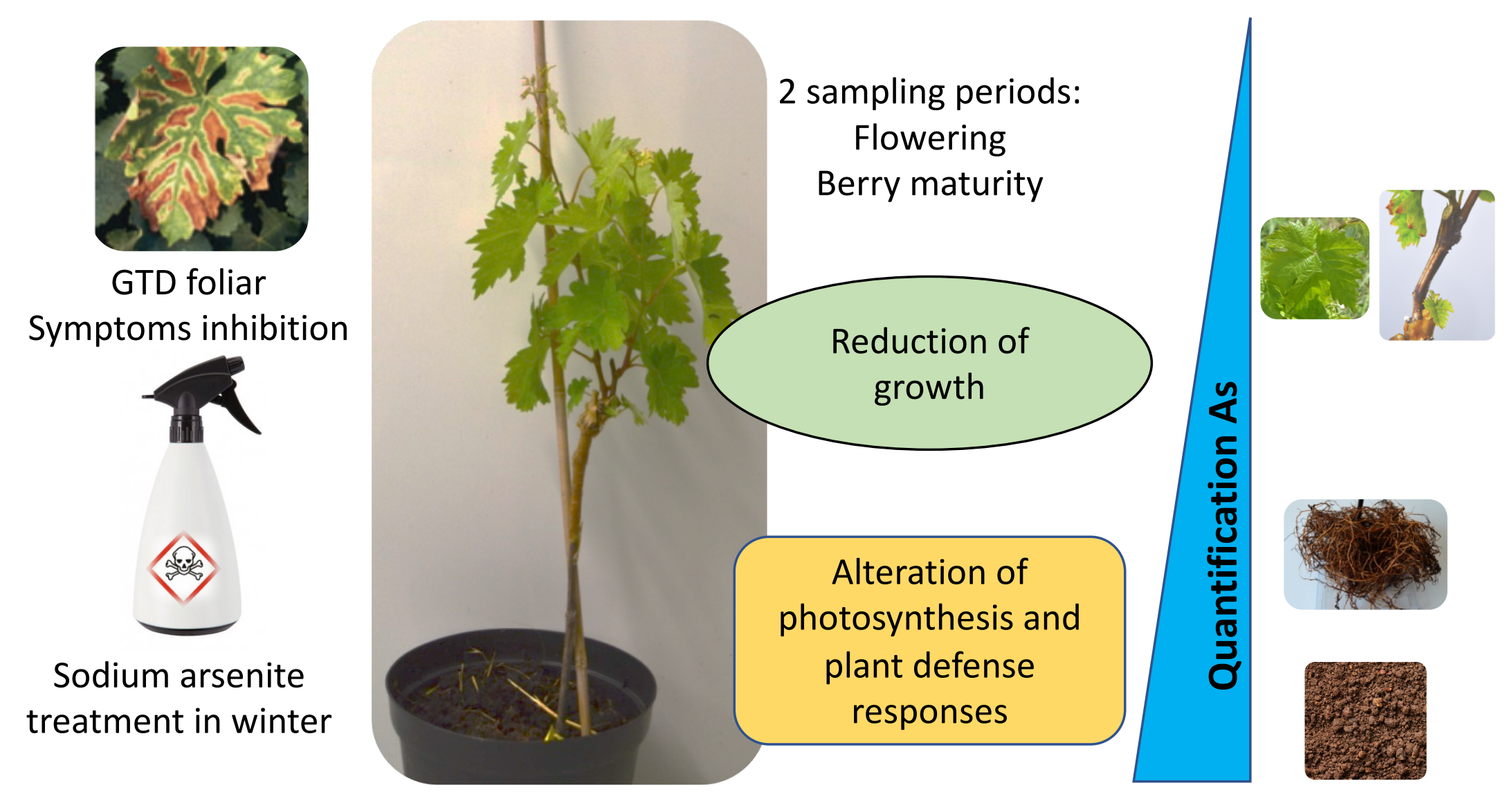

